University at Buffalo School of Law

Digital Commons @ University at Buffalo School of Law

10-23-2018

\title{
Sez Who? Critical Legal History Without a Privileged Position
}

John Henry Schlegel

University at Buffalo School of Law, schlegel@buffalo.edu

Follow this and additional works at: https://digitalcommons.law.buffalo.edu/book_sections

Part of the Labor History Commons, Law and Society Commons, and the Legal Theory Commons

\section{Recommended Citation}

John Henry Schlegel, Sez Who? Critical Legal History Without a Privileged Position in Oxford Handbook of Historical Legal Research 561 (Markus D. Dubber \& Christopher Tomlins, eds., Oxford University Press 2018)

Oxford Handbook of Historical Legal Research edited by Markus D. Dubber \& Christopher Tomlins, 2018, reproduced by permission of Oxford University Press, https://global.oup.com/academic/product/the-oxfordhandbook-of-legal-history-9780198794356

\section{C) COPYRIGHT $^{\mathrm{N}}$}

This Book is brought to you for free and open access by the Faculty Scholarship at Digital Commons @ University at Buffalo School of Law. It has been accepted for inclusion in Contributions to Books by an authorized administrator of Digital Commons @ University at Buffalo School of Law. For more information, please contact lawscholar@buffalo.edu. 
Sez Who?

Critical Legal History without a Privileged Position

John Henry Schlegel ${ }^{*}$

\author{
No more than they can we suppress \\ The universal wish to guess \\ Or slip out of our own position \\ Into an unconcerned condition. \\ Law Like Love \\ W. H. Auden
}

Back around the turn of this century when Chris Tomlins was working on the British colonization of North America, I happened to read a draft of some part of this wonderful work dealing with the language used by and about the colonizers. After reading Chris' critique all of the talk about helping the savages by bringing them Christianity and denigrating them for their uncivilized behavior, I e-mailed him with a question something like, "Can you name a conquering civilization that lamented its colonization, and so destruction, of a more advanced, more noble civilization?" Trick question, I suppose. He shot back a not quite so brusque version of, "No." To which I immediately replied to the effect of, "If such behavior is so ordinary, then why are you being so hard on this group of colonizers?" His response was typical in its directness. He stated something along the lines of, "But, if I have to accept the ordinariness of this attitude, then I can't make my argument!"

Sensibly, Chris ignored my criticism, and we are all better for his having done so, since his argument was a good one - that the bedrock of the American experience was violence toward others and not the oft trumpeted search for freedom.1 Still, this brief exchange has haunted me ever since, for it pointed at a problem that at the time I only inchoately perceived about the work of my friends, the scholars involved in Critical Legal Studies (CLS), a problem with the way that we treated our critiques as complete when we finished, as the last thing that could be said on the subject. Now the odd thing about this problem was that the targets of our critique seemed to agree with us. They acted as if disproving our assertions was the only way to deal with our critique. It seldom seemed that in response they considered mounting a critique of our own set of foundational assumptions. This too was puzzling.

* Thanks to Barry, Dan, Laura, and Fred for their help.

1. Freedom Bound: Law, Labor, and Civic Identity in Colonizing English America, 1580-1865 (2010). 
Now it is important here to remember that Chris is a partisan of critique, but in no sense a member, or even a fellow traveler, of Critical Legal Studies. So, I tell this little story because it clearly and cleanly sets up a problem with CLS history, however fine such work is, and it is fine. How was it not a problem for us that we did not critique our own set of assumptions as best as we could? How could it not be the case that we too owned and suppressed a set of debatable groundings on which we based our argument? How was it that we claimed a position outside of history and interest at the same time that we were objecting to the assumption of such a position on the part of others? It is this question that I wish to examine.

Of course, like so many things, it all started with Willard Hurst. When he strongly asserted the functionalism of law there were bound to be objectors somewhere. Whether Hurst meant "necessarily" functional I rather doubt. His notion of the "bastard pragmatism" that he saw at the root of much law, suggests that he saw functionalism as tied to reason in some way that distinguished it from narrow interest. One might put his understanding as something along the line that law is functional in the same way that, in the absence of a hammer, a crescent wrench will do to pound a nail into soft pine. This may be a way to get the job done, but in the end not a very good way, as anyone who has examined my attempts at home repairs would conclude.

CLS is one place where the objectors appeared; Bob Gordon,2 Morty Horwitz,3 and Mark Tushnet4 led the affray. In some ways Willard was a strange target. He was anything but a consensus historian.5 And he too objected to the Vietnam War, the truncation of Civil Rights achievements, the crippling of organized labor, objections that for the most part were common to CLS partisans. But he was a partisan of the Brandeisian Progressive, New Dealer type and we were not. He had faith in reason and in the ability of facts to shape it use, but an abhorrence of the ordinary uses of reason to justify private interest. While we shared his abhorrence, we did not share either of his faiths, or at least sort of did not. In the end the fight over functionalism amounted to nothing, but what it spawned was important. Critique, even Roberto Unger's “Total Critique," in Webster's words "the examination ... of a

2. 'James Willard Hurst and the Common Law Tradition in American Legal Historiography', (1975)10 Law and Society $R$ 9.

3. Or at least so I remember, though I admit I cannot find an appropriate citation.

4. 'Lumber and the Legal Process', 1972 Wisconsin LR 124.

5. Avi Soifer makes this a clear as possible: 'Willard Hurst, Consensus History and the Growth of American Law,' (1992) 20 Reviews in American History 124. 
thing or situation ... with a view to determining its nature or limitations," was to be the major intellectual approach for CLS scholars, even the historians.

In the academic world of the North Atlantic, the invocation of critique ties any activity to Kant's Critiques, and on the left to the work of the Frankfurt School, but more importantly to the idea of reason as a standing aside from the object of critique, a standing in a (privileged) place, distanced from the object, setting it apart so as to permit seeing the object in its true nature. This is, of course, also the position of the liberal narrative of law that was the object of the CLS critique (and of Tomlins' critique as well). For CLS scholars, the claim of "liberal legalism" that while small bits of law might need fixing, the great structure was fundamentally sound, was shot through with unexamined preferences for some citizens and not others, in particular preferences that established the otherness of these persons - non-whites, women, laborers. Such preferences betrayed the falsity of the cognate claim that our liberal democracy was founded on the equality of its citizens.

The CLS critique of law was extremely effective in the Eighties, so effective that it brought forth more than a bit of moral panic on the part of liberal legalist scholars, particularly those of a more politically conservative stripe. Still, as the Eighties turned into the Nineties the relevant question turned from the nature of liberal legalism to what happened to CLS: Why had it faded away? Feminist Jurisprudence and Critical Race Theory took center stage with their separate, but parallel, assertions that personal experience grounded their critiques, maybe even supplanted reason as a grounding for critique. By then almost no one remembered the scholarship of Art Leff. His devastating takedowns of both Richard Posner6 and Roberto Unger7 were mostly forgotten, as was his assertion that there can be no such a thing as a grounding for law or morals other than one based on a belief in God.8 Indeed, by then it was becoming clear that in the case of International Human Rights a pure, even primitive, positivism provided a sufficient grounding for legal action.

At the same time that these events were taking place, the American reception of the great theoretical hubbub, often emanating from France, that began with Thomas Kuhn's The Structure of Scientific Revolutions 9 and Paul

6. 'Economic Analysis of the Law: Some Realism about Nominalism', (1974) 60 Virginia LR 451.

7. 'Book Review: Knowldege and Politics', (1977) 29 Stanford LR.

8. 'Law and Technology: On Shoring Up a Void', (1976) Ottawa LR 536; 'Unspeakable Ethics, Unnatural Law', 1979 Duke LJ 1229.

9. (1970). 
Feyerabend's Against Method,10 the rediscovery of Ludwig Wittgenstein's Philosophical Investigations, 11 and then Richard Rorty's Philosophy and the Mirror of Nature,12 quieted down. Seemingly forgotten were work by Gramsci, Lukcas and Althusser, among the various Marxisms; the Structuralism of Levi-Strauss, Saussure, and Barthes; the Deconstruction of Derrida; the Post-Structuralism of Foucault and Deleuze; a good dose of Literary Theory from the likes Eagleton and Fish; the Critical Theory of the Frankfurt School and Habermas; remnants of the Existentialism of Kierkegaard, Sartre, Buber and Heidegger; Merleau-Ponty's Phenomenology; Clifford Geertz's anthropology of "thick description," and especially for the historians, E.P. Thompson's The Making of the English Working Class 13 and Whigs and Hunters: The Origin of the Black Act14, as well as the essays in Albion's Fatal Tree.15 Much of this work, though clearly not that of the historians, suggested, as had Leff, that the grounding of reason was, if not impossible, at least very, very hard.

In retrospect, the surprising thing about this Nineties quietude is not the fact itself, academia fashion changes, though usually less frequently than couturier fashion, but rather that the theoretical hubbub going on while CLS was in its heyday seemed to have had little impact on CLS scholarship. We never questioned the grounding of our own work, which often littered its star footnote with citations to, or at least wave-of-the-hand mentions of, this heterogeneous body of once fashionable work. As best as I can remember, we believed that by adopting critique and turning that method on its liberal legalist practitioners, we did not have to confront the question of grounding, in retrospect a confusion of method - lever - with grounding - a place to stand -- in our attempt to move legal scholarship and teaching, a proper Archimedean understanding of our job.

Which is not to say the fancy academic theorists questioned their own work either. Most everyone seemed to go along unself-reflexively, secure in his or her understanding that at least his or her scholarship was securely grounded, even if everyone else's wasn't. Such is, of course, a preposterous position, for much of the relevant fancy academic or CLS scholarship implicitly, and often explicitly, asserted that the thought and action that was

10. (1975).

11. (1968).

12. (1979).

12. (1963).

14. (1975.

15. (1975). 
the subject of critique was not just suffering from ignorance of the true facts, but rather that it all but intentionally hid the truth, or at the very best constructed an argument that obscured the politically loaded valence of the thought or action in question, and so elided the truth, a truth known, not empirically, but by the exercise of reason.

Thirty years ago, in the waning days of CLS, it seemed to me that the implicit problem of the grounding of truth could be solved locutionally. In an essay review of a fine piece of intellectual history,16 I reasoned as follows:

If there is no epistemologically privileged position, then I cannot know that intellectual history is better written in the fullness of such social context as one can muster. But by the same token, I am not limited to mere belief, as the notion of belief is parasitic on the notion of knowledge. Well, if I cannot know and am not limited to belief, then I guess that I am sure that I am right. At least I have given my best arguments. If you are not persuaded, try some arguments of your own. In the alternative, there is always thumb wrestling.17

As I look back, this reasoning was for me, generally a pessimist, a surprisingly optimistic assessment, as well as notably self-contradictory, for it invoked both a post-modern legal scholarship that mostly never happened in law and a modern legal scholarship that ignored the problem of grounding, of privileging a position, except when it reveled in occupying such. In such a circumstance, giving one's best arguments simply will not do. One needs to put those arguments under serious pressure, not wait for someone else to do the job. CLS historical work almost never put its arguments under any pressure. However, it seems to me that to the extent that our work can survive serious pressure, that work will be strengthened. What follows is a modest attempt to begin to undertake such a task, if only in a narrow area.

It would be easy to make my point by focusing on other than the best work. However, doing so would undermine my own argument by producing a cognate of the kind of work I am criticizing. Instead, I have chosen to look at the labor history written by CLS scholars because it is both the largest body of CLS historical work and work of an especially high quality. Moreover, friends and acquaintances have written much of this work. They have taught me most of what I know about labor history and in many cases have helped me with

16. Laura Kalman, Legal Realism at Yale. Chapel Hill, NC: University of North Carolina Press (1986).

17. (1989) 'The Ten Thousand Dollar Question', 41 Stanford LR 435, 467. 
the corresponding industrial history that is more central to my interests. Their work is worthy of my efforts. Indeed, sensible people might suggest that I am fatally overmatched.

I wish to start with a piece by Karl Klare about the work of the Supreme Court in the late Thirties, Judicial Deradicalization of the Wagner Act and the Origins of Modern Legal Consciousness, 1937-1941.18 The piece began with the altogether defensible assertion that the Wagner or National Labor Relations Act's often vague language allowed for multiple possible interpretations of its provisions. It then turned to several Supreme Court decisions that contributed significantly to the tone of post-war labor law. These decisions emphasized the centrality of labor peace such as would ensure continuing industrial production by instituting a contractual regime that would channel worker grievances into a labor-management structure that focused bargaining on wages, hours and benefits and so preserved management prerogatives over the organization of the production process. Throughout, the piece contrasted this understanding of the Act with one that might have treated democratic participation in the production process as central, an understanding that might have reduced, if not eliminated, the alienation of workers from their work by deemphasizing the importance of the contractual agreement between union and management.

A CLS detractor might explain all of these decisions by pointing out that the sit down strikes in the pursuit of union goals that occurred in these years created a reasonable fear of union disruption of production. But given the amount of management disruption of workers' lives over the previous 150 years, such an explanation is hardly worth mention, even if accompanied by the modestly rational fear of communist infiltration in the union movement. Another possible justification of these decisions, founded on the necessity for a clean demarcation of the working class from the management class, is equally unsatisfactory and for similar reasons. After all, the owners and managers of industrial enterprises regularly unsettled the lives of laborers over the same period of time. Disruption of a status quo simply won't cut it. Nor is there any reason to believe that the union movement so respected chief Justice Hughes that anything he would have written for the Court would have been a sufficient justification for these decisions. However, there is a possible, if ultimately limited, justification in the nature of the American economy at that time that surely deserved to be taken into account by CLS scholars. Still,

18. (1978) 62 Minnesota LR 265. 
to understand what that is would require knowing some of the history of that economy at least back to the Gilded Age, if not earlier.

Start with a basic truism. Real competition sucks! Operating at the point where marginal cost (including the marginal cost of capital) equals marginal revenue is damn scary. Bankruptcy is uncomfortably close. The same is even clearer for labor. The place where the last ounce of effort equals the last cent in wages puts abject poverty, if not starvation, uncomfortably close. Now, of course, as consumers, labor prefers goods sold at marginal cost and as consumers, capital prefers wages set at marginal cost, but that is not to say that the structural similarity of these positions with respect to competition suggests a real world similarity of situations. Corporate bankruptcy does not imply the starvation that may follow from the loss of a job; after all, resource endowments of capital and labor are radically different, else labor would, or at least might, draw on resources and simply reinvest, as capital has done. Still, neither capital nor labor likes living in a competitive market; both have every reason to wish to escape it. They have long tried to do so.

Before World War I big capital attempted to overcome competition by the merger of competitors to the point that the market sway of one participant was such as to create an effective monopoly, or at least to protect all of the other participants in the dominant firm's shadow. Eventually the Supreme Court made this difficult. Labor tried unionization. Here, even after securing legislation in its favor, the lower federal courts similarly managed to make unionization difficult by enjoining strikes on various grounds. Neither capital nor labor was happy with the result. Still, even more unhappy was small and medium-sized capital, the far more numerous local retailers, wholesalers, and manufacturers, who were finding that their relative, transportation-costbased insulation from local competition was being eroded by the growth of big capital.

After the end of The Great War, big capital seems to have started trying to limit competition through oligopolistic structures, though it was still extraordinarily worried about the possibility that unionized labor would upset such fragile structures. Medium and small capital, generally more dispersed geographically, tried to create similar structures through the mechanism of establishing business associations, such as the Maple Flooring Manufacturers Association, but retailers and wholesalers still felt left out.

These actions seem to have taken place in tandem with the ideas of a group of economists, called Institutionalists, who started writing before that War. They believed that economic instability was the result of excess 
production of goods and services, coupled with relentless downward pressure on producer prices caused by "chiselers" who reduced prices and otherwise "cut corners" for temporary personal advantage. These economists argued that downward pressure on prices could be resisted if producers banded together into groups that would work both to "coordinate" production (i.e., manage reduction and expansion) and to isolate and vilify chiselers, so as to enforce good - and thereby suppress "unfair" — trade practices. Their ideas coalesced into a theory called Associationalism.

This theory was essentially a Main Street, though not therefore a small town, theory. It hoped to maintain high wages through the high prices that would support small, local retail or wholesale businesses. It was not laissezfaire in a different guise, for it assumed some level of governmental involvement in the economy to remedy insufficient demand in poor times by increasing, not decreasing, employment and by providing social insurance so as to maintain the disposable income of wage earners faced with unemployment or retirement. Which is not to say that as a general matter either capital or labor supported the whole package, but it was a package that attracted some progressives in the years after the World War I and that obviously informed much New Deal legislation, both that found constitutional and that found unconstitutional.

It is also true that these ideas are redolent of Spanish, Italian and German corporatism that turned Fascist in the mid-Thirties. However, at the same time it is possible that such ideas were attractive on their own as a way of mediating between the claims of capital and labor, granting capital some protection from sudden bankruptcy and labor some protection from declining income. It is not hard to see Associationalism as implying exactly what happened, a law that recognized the centrality of labor peace such as would ensure continuing industrial production under a contractual regime that would channel worker grievances into a labor-management structure that focused bargaining on wages, hours and benefits and so preserve management prerogatives over the organization of the production process.

In order to effectively criticize this regime it is not enough to say that from the perspective of radical labor it denied workers their rights to selfdetermination in structuring their employment and the production process, any more than it is enough to say that from the perspective of radical capital it would be sufficient to criticize this regime for failing to allow capital to exclude labor from any role in structuring the terms and conditions of employment. One would at least need to recognize that in these years competition had been experienced as sufficiently inimical to the interests of 
both capital and labor so that both had reason to dampen it.19 The desire to limit competition might well explain the choices that the Supreme Court made in the early years of interpreting the Wagner Act.

Next consider a piece about a much earlier period in American labor history, Wythe Holt's Labor Conspiracy Cases in the United States, 1805-1842: Bias and Legitimation in Common Law Adjudication.20 The piece examined all the reported early Nineteenth Century cases in which unions of journeymen were charged with common law criminal conspiracy for evidence of antiunion bias. These years experienced a continuing breakdown of the once traditional relationship of the irregular, but shared, work schedule of masters and journeymen in urban areas in both the clothing and shoemaking trades and its replacement with the growth of more regular, but no longer shared, work schedule punctuated with layoffs of indefinite duration - an early approximation of factory employment. The journeymen objected to these changes and in response they formed unions to fight for better wages and terms of employment. Masters responded by bringing charges that these unions were engaged in a criminal conspiracy. The journeymen's arguments in defense of their unions centered on the loss of worker independence, selfesteem, and local communal estimate of worth, all of which were related to the changes in working conditions.

The varying reports of these cases quite clearly illustrated the claim of bias against the journeymen on the part of the various judges who ruled for employers in these cases. However, the piece did not stop there, but also identified the causes of the change in working conditions in significant detail urbanization, expansion of urban markets, growth of an Atlantic market economy subject to periodic disruption followed by reinvigorated competition, and in-migration of both domestic farm workers and foreign laborers. Still, in this piece these causes seem to be related to, and justify the actions of, the journeymen alone. This is strange.

If competition sucks, change in the circumstances of competition sucks even more. The stability of the master-journeyman-apprentice relationship was pretty much dependent on limited or even absent local competition. Competition was limited by the combination of the geographic structure of the

19. Both Holmes - Vegelahn v. Gunther, 167 Mass. 92, 108-9 (1896) and Plant v. Woods, 176 Mass 492, 505 (1900, dissent) -- and Brandeis - Hichman Coal \& Coke Co. v. Mitchell, 245 U.S. 229, 271 (1917, dissent) - understood this point, though not in precisely the same way. 20. (1984) 22 Osgoode Hall LJ 591. 
local area and the cost of transportation. Limited competition allowed for informal constraints on price by producers, as well as local social constraints on avarice, and so allowed marginal revenue at least modestly to exceed marginal cost. Absent competition abetted the maintenance of social relations between the three statuses, often in a combination with shared residence and working space.

Significant urban growth and a reduction of transportation costs both increased competition; together they were even worse. The piece recognized that the increase in the size of port cities, in part by in-migration from surrounding rural areas and Northern Europe, and in part by the expansion of the Atlantic market, both littoral and oceanic, significantly changed the terms of competition among the masters. This change thus threatened both the economic and social position of what it meant to be a master. Possible responses to this change were several. Some older masters could effectively retire; others might concentrate on up market niches where price was less important. However, for most masters the major alternative to the slow decent into bankruptcy was to abandon the master-journeyman-apprentice model of the trade to a greater or lesser extent. Whether choosing to cut back on the enrollment of apprentices or to move into real factory production and so expand the number of employees who would formerly have been treated as apprentices, or even to try developing a model of something in between, the strategy of economic and social survival chosen by most masters was that of reducing the cost of labor. Process innovation was unlikely to reduce costs significantly, and even if it did, the advantage it provided was likely the same - reducing the cost of labor.

Thus, it was anything but surprising that it was the journeymen who felt squeezed by the alteration in the terms of competition and for whom unionization was an obvious response. Nor was the response of the masters to unionization surprising as they were being squeezed too. Both parties were finding that their economic and social status was under assault. Both were fighting to maintain that status in a world where urbanization, inmigration and changes in transportation were fraying the social bonds on which the apprentice-journeyman-master system depended for its maintenance. Neither group was acting implausibly. In a world where, economically speaking, sunk costs are sunk and so should be ignored by each group, the sunk human capital that was under threat of being rendered less valuable was a life. Lives are not an easily dispensed with as might be an outmoded lathe or a no longer needed hand tool. Indeed, the capital recovery 
period for a life is probably longer than that life itself, extending forward at least until one's children are well settled.

Here then the choice that law made in this time of economic disruption was not just between labor and management, as this piece asserts and as is plainly the case, but also a choice between two groups that were seeing their settled lives upended, just as was the case with the Wagner Act in the Nineteen Thirties. One group chose to attempt to organize collectively and the other appeared not to, though, of course, it would have been much easier for the masters to hide their cartel, if there were one, than for the journeymen to hide their union.21 And so facially the courts were doing exactly what they said -- holding both groups to the identical competitive standard, while at the same time ignoring the difference in the resources that each could bring to address the change in economic and social circumstances that threatened both groups' lives. And so, it is less the obvious class bias in the courts of law that the piece so clearly documents that is troubling. After all, such is a constant in the history of law. Rather, it is the difference in response to similar threats to the social and economic position of both groups in this time of economic turmoil on the part of judges.

Dianne Avery dealt with the years in between Klare's piece and Holt's. Images of Violence in Labor Jurisprudence: the Regulation of Picketing and Boycotts, 1894-192122 focused on opinions in litigation, primarily in the federal courts, and of Supreme Court Justices, most of whom were active during the heydays of the laissez faire Gilded Age. In great detail it first derived and then traced out the impact of the judicial understanding that workers were irrational and easily prone to violence, especially when under the influence of "outsiders," persons not part of an individual factory's workforce. For these judges such a propensity to violence meant that any resort to more confrontational economic weapons than the strike (a passive unwillingness to work), weapons such as picketing and boycotts, needed to be very carefully policed lest they interfere with employer's rights of property.

The piece made it clear that it was not just labor that could be described as being prone to violence. As Brandeis and Holmes recognized, the idea of a somehow uncoercive economic warfare was implausible.23 The economic warfare between producers that was part of legally approved competition was

21. This point was made some years ago by a man named Adam Smith: The Wealth of Nations, Bk. 1, chap. 8, Paras. 11, 12 \& 13 (5 ${ }^{\text {th }}$ Ed. 1789).

22. (1988) 37 Buffalo LR 1.

23. Supra note 19. 
just as coercive, just as threatening to the rights of property, as anything that workers might do. Still, the failure of judges to see this equivalence made it clear that that when limiting labor action to activities that were not coercive, judges in fact preferred one of the parties in a labor dispute.

At several points Images of Violence noted the economic disruption that characterized the laissez fare years. The combination of the final build-out of the rail transportation system, the great growth of metal bending technology, and the growth in immigration from Southern and Eastern Europe significantly increased the level of competition both between manufacturers and between workers. The adoption of the Sherman Anti-Trust Act showed how quickly manufacturers saw merger, and so growth of geographic scope, as a possible way to regain a modest control over pricing that market expansion had reduced. Similarly, the adoption of the Interstate Commerce Act showed how quickly both farmers and rural manufacturers became dependent on rail transport to build market access and the degree to which freight rates impacted such access, even for business that were on railroad mainlines. Perhaps, equally importantly, the Civil War was understood as a lesson in the economic importance of unimpeded railroad transport for the economy as a whole.

In competitive circumstances such these, smaller producers felt an intense production-related cost pressure. Larger producers who had generally engaged in various financial shenanigans to reach such size found that similar pressures were magnified by the fiscal discipline of the debt repayment schedule that regularly accompanied such expansion. All of these pressures were augmented by the seeming necessity of ever increasing expenditures for capital goods that accompanied technological change. For firms of either size the major cost that could be controlled when competition brought price pressure was wages, or so it seemed to management. For labor such cost control through wage reduction, head-count reduction, skilled labor reduction, the dreaded speedup or often a combination of all four, amounted to a decrease in economic and social status/security. For management a possible inability to control costs also amounted to a similar decrease in economic and social status/security.

This last statement with the introduction of the word "management" shows the degree to which the years that this piece explored were different from the years before the Civil War. The masters were management and owners as well. The possibility of shifting language from "master" to "management" indicates the degree to which the separation of ownership and 
control, so firmly attached to scholarship of the late Twenties, was already in full swing in the Gilded Age Nineties. Andrew Carnegie may have "owned" Carnegie Steel, but the fact that his ownership was so noteworthy indicates how unusual such a circumstance already was. One may identify John D. Rockefeller with Standard Oil, but he was not that firm's owner in the sense that Carnegie owned Carnegie Steel; Henry Ford did not secure both ownership and control until he brought out the Dodge brothers in 1919.

Owners, so-called stockholders, often had different concerns than managers, and large stockholder managers more different still. For a manager the threat of economic failure was in some real sense the same as such failure was to a worker -- job loss, diminished income, a lower standard of living and a concomitant decline in social status, unless job search quickly resulted in securing equivalent employment, a pretty iffy possibility - though of a different magnitude for workers than managers. Stockholders faced a loss of income, often substantial given that the stockholder with a well-diversified portfolio didn't appear on the economic scene until after World War II. But in most cases an even modestly diversified stockholder had wealth concentrated in only a few equity positions and so the loss of one such position might mean a significant decline in the value of one's estate.

While there is little reason to cry over such a relevantly large loss destitution was unlikely to be the result - smaller losses might be thought of differently given that corporate debt and even preferred stock was owned in small amounts, often as part of a sort of do-it-yourself retirement plan, by the much larger group of families who qualified in some sense as middle class. Yet, even these supposedly more secure investments had a bad habit of becoming valueless at the same time that the issuer declared bankruptcy, at least in the case of manufacturing companies. For such middle class owners a decline in social and economic status was also likely and new jobs hard to find.

Owner stockholders, so-called controlling persons, were in these years, primarily family and friends of the founders of the original business. In many cases these people were leaches on the tits of capitalism, more concerned about maintaining social status and lifestyle than about any particular investment. But not always; often they were unwittingly friends of the workers, especially when out of sentiment for the founders they pushed to keep the business alive far longer than a heartless capitalism would dictate based on the notion that sunk costs are sunk.

Again, I am not arguing for the moral equivalence of capital and labor, any more than I argued for such equivalence in the Early Republic or the 
Nineteen Thirties. Capital always has more options for recovery from an economic setback than labor and thus is more able to be generous. But, what I am arguing is that it is not surprising that when trying to understand behavior at a time when the species of capitalism that the law confronted was about as close to dog-eat-dog as sensible people might wish, one needs to understand why capital might have felt itself to be as much under siege as did labor.

Capital's response to labor in the Gilded Age and thereafter was not just a reflexive ideological defense of itself, though there was quite a bit of that, but also it was a response to the same forces that made labor's lot so awful. And equally important, capital was not an undifferentiated "it." Capital represented groups of people in many situations with many different concerns, only some of which I have identified. A stronger argument for the inappropriateness of the consistent understanding of labor violence that the courts peddled in these years would have recognized the degree to which that understanding responded only to what some capitalists experienced, individuals whose response came from a place closer to that of labor than anyone was willing to admit.

The Development of the Employment at Will Rule,24 by Jay Feinman, helps to bring my point about the differential similarity of capitalism's creative destruction home once again. This piece reviewed the slow alteration of the American version of the traditional English rule that a hiring for other than a specified duration is presumed to be for one year. As, in the years before the Civil War the most common hirings slowly changed from agricultural and domestic to commercial and manufacturing, doctrinal confusion seemed to increase, both in the cases and on the part of the treatise writers. After that war, bargain theory of contract entrenched itself at the same time that litigation slowly shifted to claims made by middle managers whose employment opportunities increased as businesses grew in size. Most of these cases thus turned on questions of the intent of the parties. After a series of contradictory cases in New York, the major commercial jurisdiction in the United States, all of which involved middle managers, in 1895 the matter was finally settled by the New York Court of Appeals with the explicit adoption of the employment at will rule, a rule that quickly spread throughout the and.

It is fitting that this bit of law should solidify in the high Gilded Age and right after the great Panic of 1893. Middle management was the last part of economic life that had a claim to being something other than either owners or

24. (1976) 20 American Journal of Legal History 118. 
workers, neither capital nor labor. It was a precarious status at a time when competition was so cut throat. In such an era everyone was expendable. Not surprisingly, middle management was not again treated well until after the New Deal and wartime destruction overseas reduced competition to an oligopolistic minimum, but even then "at will" survived, whatever might have been the then middle manager's expectation of future employment.

Little understanding can be found in the CLS literature of the circumstances of fired middle managers. Workers, yes; management, no; much less owners of various kinds whose businesses became bankrupt. And yet, all of these people have families, suffer loss, surely not the same loss, but loss nevertheless. In this way CLS history suffers from the problem that we regularly asserted was inherent in the work of in our liberal legalist opponents - the belief that our perspective was timeless, privileged, true even. But critique, whether based on class, ethnicity, gender or sexuality, is no more privileged than that of the object of critique. Neither research nor personal experience establishes the truth of an interpretation of events. The high ground is to be found with the recognition that there is no such thing... for nobody.

That history is part of a world in which one cannot know, but is not therefore limited to belief, as I wrote earlier, does not mean that one cannot say anything with an appropriate level of assurance, a politics even. In our writing we choose who are the winners, who are the losers, and sometimes even who are the also-rans. But no matter what our choice is, the question remains: With what degree of assurance may we speak? Who sez? Here I would argue that assurance is greater when one recognizes and accounts for those whose understanding of the events in question does not square with one's own. Such an understanding is appropriate not because it is fairer -that proposition is silly -- but because it is more human - compromised, fallen even, self-centered, and best understood in a lived context that for each of us combines both the comfort of present circumstance and the fear of change that may threaten social and economic position in scary ways. This is even true when telling stories in which we believe that "the good guys" won, not everything - law is always trumped by culture to a greater or lesser degree but something. No matter how important the achievement may be, there will always have been losers, at least from their perspective, people who believe that their social and economic position has been diminished. It is by recognizing their loss that we strengthen our win by validation their, and thus our, common humanity. 
Consider the Tomlins' work I spoke of at the outset. It seems relatively obvious that the explorers and colonists that he speaks about were pretty scared in this world that was new to them, despite the vast difference in weaponry between themselves and the people already settled in North America. It seems fairly common, ordinary even, that people who find themselves in what they take to be scary places make up stories that justify their behavior in these places. Such stories appear in the news every week with respect to white people in black neighborhoods. Recognizing this likelihood would not diminish the power of Tomlins' story, rather, by taking these peoples' fears (on both sides) seriously and accounting for both those real fears and the brutal reactions they brought, his story would be strengthened, just as would be the case with CLS historians writing about the workers, managers, and masters/owners faced with economic change in CLS stories about labor history.

Now, none of this criticism should be taken to suggest that the CLS labor historians should be faulted for the history that they actually wrote. There really was no other choice. They. Like tomlins, told stories that cried out for the telling since they had never before figured prominently in the tale of law in America. Thus the fault, if there be fault, as opposed to another of the endless list of examples of historians "doin' what comes natur'lly," was on the part of the liberal legalist historians who should have included the stories of American workers, indeed of democracy's losers of all kinds, in their telling of the story of the triumph of American law and legal culture. Their scholarship, like ours, would have been made stronger had they recognized loss as they wrote of what they saw as gain. Having not done so, the temptation to highlight their error was simply too tasty to pass up. CLS historians enjoyed the feast.

I hope that what I have said is not interpreted to mean that I believe in the possibility of writing "objective" history. Auden captures the human desire to "slip out of our own position," but he also recognizes the impossibility of doing so, except as a boast. Yes, dates and places and texts can be known in the way that astronomers know that that big yellow-orange ball that appears in the sky with some regularity is a star around which our planet orbits, but as soon as an historian tries to give shape, and so meaning, to what in the words of William James is that "blooming, buzzing confusion" of particularities by including and excluding, emphasizing or deemphasizing things, any plausible claim to objectivity goes out the window. 
Historians live in the world that Peter Novick so trenchantly described as That Noble Dream.25 We are always trapped by our past and our present, by our race and ethnicity, our gender and sexual orientation, our education and class position, our toilet training and other rebellions. All of these things preclude us from ever acquiring either an "unconcerned" or a privileged position. But being trapped does not mean that we have no obligation to do our very best to understand the many worlds of the people in our various stories about the past. We need to understand, and not in caricature, simultaneously both the workers and the capitalists, the feminists and the misogynists, the racists and the objects of their vilification, the urbanists and suburbanists and ruralists, the adherents of various religions and those without such beliefs.26 This is not because their beliefs and actions are of equal value -- our writing ultimately discloses how we value them, as it should -- but because they are all humans, all trapped in their past and present just as we historians are, and so our efforts to understand them tells us something about the world that our species instantiates. And, after all, that is the point of studies in the humanities and social sciences, studies that history is a part of.

After reading a less fleshed out version of this piece, Barry Cushman impishly asked, "Can you name a successful critical reform movement that devoted a lot of effort to analyzing and critiquing its own animating foundational assumptions?" And so I am pleased to return to where I started, but with a more modest answer this time, though not obviously Chris Tomlins' answer. I know that the answer to Barry's question is "No," but as an intellectual utopian -- my fifty year of attempting to identify and sell a less awful curriculum for the first year of law school ought to be sufficient evidence - that "No" does mean that we of the party of the left should not try. As a utopian I believe that when not in a Maoist mode, self-criticism would more fully reflect the position that scholars, especially the historians whose work I know and love, are in when and whatever they write. And I hope that such more capacious reflection on the limitations of positionality just might

25. (1988).

26. Dan Ernst reminds me that such will not be easy, for when he made a similar assertion in presenting the chapter on the Danbury Hatters Case from his book Lawyers Against Labor: From Industrial Rights to Corporate Liberalism (1995) at the labor history meetings, the great labor historian David Montgomery protested, "I'm supposed to feel sorry for a capitalist?" Had I been there, I hope that I would have had sufficient courage to have spoken in Dan's defense and answered, "No, for a human." 
allow our critique to be effective for more than the statutory fifteen minutes of Warholian fame. If you disagree, stop by for some thumb wrestling.

\section{Additional Reading}

James B. Atleson, Values and Assumptions in American Labor Law (1983). Craig Becker, 'Property in the Workplace: Labor, Capital and Crime in the Eighteenth-Century British Woolen and Worsted Industry', (1983) 69 Virginia LR 1487.

Louis Galambos, 'The U.S. Economy in the Twentieth Century', in Stanley L. Engerman, Robert E. Gallman (eds.), 2 The Cambridge Economic History of the United States (2000), 969.

Colin Gordon, 'Workers Organizing Capitalists: Regulatory Capitalism in American Industry, 1920-1932', in Colin Gordon, New Deals: Business, Labor and Politics in America, 1920-1935 (1994), 87.

Alfred S. Konefsky, "'As Best To Subserve Their Own Interests": Lemuel Shaw, Labor Conspiracy, and Fellow Servants', (1989) 7 Law and History R 219.

Naomi Lamoreaux, ,'Entrepreneurship, Business Organizations \& Economic Concentration', in Stanley L. Engerman, Robert E. Gallman (eds.), 2 The Cambridge Economic History of the United States (2000), 403.

Jonathan Levy, Freaks of Fortune: The Emerging World of Capitalism and Risk in America (2012).

D.W. Meinig, The Shaping of America: Transcontinental America, 1850-1915 (1998).

D.W Meinig, The Shaping of America: Global America: 1915-2000 (2004).

Pierre Schlag, The Enchantment of Reason (1998).

John Henry Schlegel, 'Notes Toward an Intimate, Affectionate and Opinionated History of the Conference on Critical Legal Studies', (1984) 36 Stanford LR 391.

Philip Scranton, Proprietary Capitalism: The Textile Manufacture at Philadelphia, 1800-1885 (1983).

Martin J. Sklar, The Corporate Reconstruction of American Capitalism, 18901916: The Market, the Law and Politics (1988).

Robert Steinfeld, The Invention of Free Labor: The Employment Relation in English and American Law and Culture, 1350-1870 (1991). 